in 1966 and that the colony has been subsequently reduced in size. He also reported that one person took a few dozen eggs from that colony in 1969. Yost (pers. comm.), dwelling in the vicinity of the active heronry southwest of Fife Lake, reported that the herons probably moved from west of Rock Glen to their present site because of human disturbance. The birds still are shot at occasionally but Mr. Yost does what he can to prevent this. We hope that readers will watch vigilantly for any form of human disturbance to heronries in their locality.

\section{Acknowledgments}

Many naturalists and wardens provided information or gave assistance in locating heronries. Special thanks go to Dr. C. S. Houston, Saskatoon, who provided a detailed list of heronries, D. W. A. Whitfield, Saskatoon, who located several new heronries along rivers by plane, R. Isbister, Edmonton, who surveyed the heronries at Churchill, Kazan and Lavallée Lakes and J. E. Polson and T. Donald, who conducted a brief and preliminary survey in 1969.

\title{
A THIRD RED-BELLIED WOODPECKER RECORD FOR SASKATCHEWAN
}

\section{by Frank H. Brazier, 2657 Cameron Street, Regina}

Reclining at ease in the shade of several tupelos, popularly known as "black gums", I often watched the comings and goings of a family of Red-bellied Woodpeckers at a feeder in a Louisiana garden. I also saw this attractive and distinctive bird often during a recent visit to Florida.

Because I am familiar with the Redbellied Woodpecker (Centurus carolinus) through my travels in the southeastern United States, I was sure when I wandered into Manley Callin's front yard at Fort San, Saskatchewan, on July 19, 1970, that a woodpecker which landed on a power-line pole about 100 yards away belonged to this species. A Yellow-shafted Flicker was nearby on the pole, so I could see that the newcomer was smaller, about Hairy-sized. The size of the bird and the absence of the typical Hairy Woodpecker pattern when viewed sideways at that range sent me racing for my binoculars which I had left in my car. A few seconds later my $10 \times 50$ 's brought it well into viewing range. It had obligingly shifted a quarter-turn to the left around the pole, giving me a fieldguide view of the back; the red over part of the nape, the gray crown and the fine-barred back left no doubt that I was seeing a Red-bellied Woodpecker. The size of the nape patch indicated a female.
This was the third Red-bellied Woodpecker I had seen in Saskatchewan, and I was sure that it would be a first record for Fort Qu'Appelle and the vicinity, and a "lifer" for Manley Callin. Unfortunately, however, Manley failed to hear my call and I had to run in to get him. Returning, we scoured the neighbourhood fruitlessly for some time. Then, when poking through the bush bordering a meadow (those who were at the first annual June field meeting of the Saskatchewan Natural History Society and saw the breeding Yellow-breasted Chat would know the spot), a bird flashed by and perched briefly on a dead tree limb before vanishing into the foliage, long enough for me to get a few seconds' view through the glasses. It was enough to convince me, though I had only a low-angle look, that it was the same bird.

Saskatchewan's first Red-bellied Woodpecker, a female, was seen in the Legislative Grounds in Regina on May 23-26, 1959 (Blue Jay, 17:95). I had seen that bird and, at practically the same spot, on October 12, 1961, a male of this species flew to a tree within a few feet of me. Lucy Eley later mentioned that she had seen a Red-bellied Woodpecker in that vicinity on about that date. 